九州大学学術情報リポジトリ

Kyushu University Institutional Repository

Status of Wild Grape Cultivation and

Distribution in Korea Focused on Paju City in Gyeonggi Province and Muju County North Jeolla Province

Lee, Sang Hyun

Faculty of Forest Science, Chonbuk National University

Kang, Hag Mo

Gyeonggi-do Forest Environment Research Station

Choi, Soo Im

Korea Forest Research Institute

Seo, Byung Soo

Faculty of Forest Science, Chonbuk National University

他

https://doi.org/10.5109/9309

出版情報：九州大学大学院農学研究院紀要. 52 (1)，pp.229-237，2007-02-28. Faculty of Agriculture, Kyushu University

バージョン：

権利関係 : 


\title{
Status of Wild Grape Cultivation and Distribution in Korea Focused on Paju City in Gyeonggi Province and Muju County North Jeolla Province
}

\section{Sang Hyun LEE ${ }^{1}$, Hag Mo KANG ${ }^{2 *}$, Soo Im $\mathrm{CHOI}^{3}$, Byung Soo SEO ${ }^{1}$, Hyun Kim ${ }^{1}$, Young Jin $\mathrm{CHO}^{1}$, Ho Sub LIM ${ }^{1}$ and Katsuhisa KOHROKI}

\author{
Laboratory of Forest Policy, Division of Forest Environment and Management Sciences, \\ Department of Forest and Forest Products Sciences, Faculty of Agriculture, \\ Kyushu University, Fukuoka 812-8581, Japan \\ (Received November 9, 2006 and accepted December 1, 2006)
}

\begin{abstract}
Wild grapes are grown throughout Korea as a short-term income crop of forest products, and a part of measure to deal with the Uruguay Round. Local governments are providing farm assistance and helping growers to construct facilities needed to grow wild grapes. However, this fruit is produced excessively, and not sold readily due to the difficulty in finding appropriate distribution channels in recent years. In this study, the level of wild grape production in Paju City in Gyeonggi Province and Muju County in North Jeolla Province, and distribution channels were examined to seek ways for the growers to gain more profits. The results showed that the growers need 1) systematic growing techniques to produce premium grade wild grapes, 2) the expansion of cooling facilities to store their product long enough for distribution without damaging the product, 3) support from the local government to recover from natural disasters and to assist processing facilities, and 4) on-going sales and promotion activities through various media, such as the Internet. Nonetheless, more efforts area needed such as discovering other income crops along with support for these growers, such as securing distribution channels for stable sales.
\end{abstract}

\section{INTRODUCTION}

It was about 15 to 20 years ago when Korean farmers started to grow wild grapes depending on different regions. Wild grapes were processed into different products such as wine in the mid 1990's. The so-called wild grapes grown in Korea are a cross breed between grapes and wild grapes (Vitis Fexuosa) (Korea forest Service, 1993) in which slip cuttings were obtained from the resulting seedling and grown into wild grape trees. They are grown throughout Korea including Paju City in Gyeonggi Province, Pyungchang County and Goseong County in Gangwon Province, and Muju County and Imsil County in North Jeolla Province. Compared with the year 2000, the level and value of production were increased by three-folds in the year 2004 at $993,704 \mathrm{~kg}$ and 3.2 billion won, respectively. The level of production was the highest in North Jeolla Province, followed by Kunggi, Gangwon, and North Kyungsang Provinces (Table 1). As a forest product, wild grapes offer a good prospect as a short-term income generating crop for farmers who need to compete with other farmers in the world with the Uruguay Round. Especially, they are not labor intensive (Kim and Kim, 1995), providing an advantage in Korea where labor cost is expensive, so that local governments have extended support to the growers of this crop. However, the level of production is excessive, resulting in price drop. Moreover, they are

Faculty of Forest Science, Chonbuk National University, Chonju, 561-756, Korea

Gyeonggi-do Forest Environment Research Station, Osan, 447-290, Korea

Korea Forest Research Institute, Seoul, 130-712, Korea

* Corresponding author (E-mail: kanghagmo@hanmail.net) not sold readily due to lack of recognition by Korean consumers, and processed goods, such as wild grape wine are competing with imported wine but not faring well. Despite all these difficulties, there has not been a quantitative study on wild grape growers in Korea. Therefore, this study was conducted to obtain actual statistics from wild grape growers in Korea in order to identify problems with wild grape growth, and point out the direction of better future for these farmers.

\section{METHODS}

The study was done by surveying large wild farms in which 23 wild grape farms in Juksong Myun, Paju city in Gyeonggi Province, and 22 farms in Juksang Myun, Muju County in North Jeolla Province. The survey was done through interviewing the growers for 1 month from early March to early April, 2006. The items related with production such as labor force, employment status, income, land used for wild grape growth, and crops grown were investigated. The size of wild grape farms, their production levels, and distribution status were also investigated. The results obtained were categorized into different regions, years, levels of wild grape production, and sizes of farm and analyzed by a category.

\section{RESULTS AND DISCUSSION}

General Situation of Wild Grape Cultivation and Production Levels in the Investigated Regions Paju City in Gyeonggi Province

In Paju City in Gyeonggi Province, there were 80 farms growing wild grapes in a total land size of 65 ha at a total production level of 600 tons, giving a total of 1.3 billion won with each farm income of 16 million won in 
2005. In 2006, 160 farms grow wild grapes in a total land size of 240 ha at a total production level of 2,200 tons, giving a total of 1.3 billion won with each farm income of 28 million won. Thus, the size of wild grape growth and per farm income were increased by about four folds and two folds, respectively, compared with the year 2005. In 2005, 1.34 billion won was invested to build underground aging room space and storage facilities. In 2006, a 630 million won budget is set aside to build facilities to produce and process wild grape wine. Profits made were 490 million won between 1999-2006 by exporting 127,350 kg of wild grape juice and wine to Japan, Singapore, Hong Kong and the United States, and 2.02 billion won in 3 years between 2003-2005 (Paju City, 2006).

Muju County in North Jeolla Province

In Muju Kun in North Jeolla Province, 178 farms grew wild grapes in 80 ha land, producing a total of 800 tons in 2005. For 3 years between 2001 and 2003, a total investment of 440 million won was made with the farmers paying $40 \%$ of this investment. Four wineries are located in this area, and produce 327 tons of wine and sold 300 tons yearly. However, one winery has a stock of 280,000 bottles of wine, but sold only 10,000 bottles so far and expressed difficulties exporting wild grape wine.

\section{Statistics Related with Wild Grape Farms}

\section{Production Structure}

Labor Force Composition

Among 45 farms investigated, a total of 104 workers were present, who were older than 20 years of age, resulting in 2.3 workers per farm. In Paju city in Gyeonggi Province, the average number and age of workers were 2.3persons and 64 years, respectively. In Muju County in North Jeolla Province, they were 2.3 and 62 , respectively (Table 2 ).

Excluding Those Under 20 Years of Age

The most prevalent age of labor force was the 60's at $34 \%$, followed by over 70 years of age at $29 \%$ and the 50 's at $16 \%$. In Paju City, it was the 60 's and older than 70 years of age at $37 \%$ and $24 \%$, composing $61 \%$ of the total work force. In Muju County, over 70 years of age and the 60 's were $34 \%$ and $30 \%$, respectively, composing $64 \%$ of the total work force. Thus, the work force was older than that in Paju City. On the other hand, the employment status in Paju City showed that among 54 people surveyed, 4 persons were regular forest workers, whereas 4 were temporary workers. In Muju County, 1 was regular forestry worker, 1 was self-employed, and 3 were temporary workers among 50 people. This low employment status is probably due to difficulty finding jobs in older people and family-oriented farming structure (Table 2).

Table 1. Yearly and regional wild grape growth in Korea

\begin{tabular}{cccc}
\hline \multirow{2}{*}{ Classification } & Amount & $(\mathrm{kg})$ & $\begin{array}{c}\text { Value } \\
\text { (mil won) }\end{array}$ \\
\hline \multirow{3}{*}{ Year } & 2000 & 289,789 & 1,217 \\
& 2001 & 305,742 & 1,316 \\
& 2002 & 577,691 & 2,018 \\
2003 & 653,410 & 2,484 \\
& 2004 & 993,704 & 3,229 \\
\hline \multirow{5}{*}{ Province } & North Jeolla & $437,385(44.0)$ & 1,356 \\
& Gyeonggi & $314,341(31.6)$ & 729 \\
& Gangwon & $114,058(11.5)$ & 660 \\
& North Kyungsang & $61,325(6.2)$ & 215 \\
& South Kyungsang & $33,057(3.3)$ & 101 \\
& North Chungchung & $31,700(3.2)$ & 9
\end{tabular}

Note: The number in parenthesis is the $\%$ ratio

Data: Korea Forestry Service. 2005. Annual statistics of forestry. 35: 298

Table 2. Status of labor composition

\begin{tabular}{|c|c|c|c|c|c|c|c|c|c|}
\hline \multirow{2}{*}{$\begin{array}{l}\text { Households } \\
(\mathrm{H})\end{array}$} & \multicolumn{3}{|c|}{ Total } & \multirow[b]{2}{*}{ 20's } & \multirow[b]{2}{*}{30 's } & & & & \\
\hline & Total & $\begin{array}{l}\text { Total } \\
\text { Males }\end{array}$ & Females & & & 40's & 50 's & 60 's & $\begin{array}{c}\text { Over } 70 \\
\text { years }\end{array}$ \\
\hline $\begin{array}{l}\text { Total } \\
(45 \mathrm{H})\end{array}$ & 104 & 51 & 53 & $\begin{array}{c}1 \\
(1.0)\end{array}$ & $\begin{array}{c}8 \\
(7.7)\end{array}$ & $\begin{array}{c}13 \\
(12.5)\end{array}$ & $\begin{array}{c}17 \\
(16.3)\end{array}$ & $\begin{array}{c}35 \\
(33.7)\end{array}$ & $\begin{array}{c}30 \\
(28.8)\end{array}$ \\
\hline $\begin{array}{c}\text { Paju City } \\
(23 \mathrm{H})\end{array}$ & 54 & 27 & 27 & - & $\begin{array}{c}6 \\
(11.1)\end{array}$ & $\begin{array}{c}3 \\
(5.6)\end{array}$ & $\begin{array}{c}12 \\
(22.2)\end{array}$ & $\begin{array}{c}20 \\
(37.0)\end{array}$ & $\begin{array}{c}13 \\
(24.1)\end{array}$ \\
\hline $\begin{array}{l}\text { Muju County } \\
(22 \mathrm{H})\end{array}$ & 50 & 24 & 26 & $\begin{array}{c}1 \\
(2.0)\end{array}$ & $\begin{array}{c}2 \\
(4.0)\end{array}$ & $\begin{array}{c}10 \\
(20.0)\end{array}$ & $\begin{array}{c}5 \\
(10.0)\end{array}$ & $\begin{array}{c}15 \\
(30.0)\end{array}$ & $\begin{array}{c}17 \\
(34.0)\end{array}$ \\
\hline
\end{tabular}

Note: 1) The number in parenthesis is the ratio (\%)

2) Excluding those under 20 years of age 


\section{Status of Land Cultivated}

Among 45 farms investigated in Muju County, 2 farms did not have land and 43 farms owned 58.4 ha. The average land per farm in Paju City was 1.6 ha and in Muju County was 1.0 ha, showing a difference, which is due to 1 farm in Paju City cultivating 10 ha of land. The number of farms that owned their forestry was small in which it was 2 in Paju City (0.7 ha and 18.0 ha) and 1 in Muju County (0.7 ha) (Table 3).

Status of Crops Cultivated

Among 45 households investigated, 43 owned land in which among the crops cultivated, rice was the predominant crop in both regions. But in Paju City, ginseng and zucchini were the crops planted the most following rice, whereas in Muju County, they were kadsura and red pepper (Table 4).

Status of Land Purchase and Sales

The status of land purchase showed that the area of rice paddies, fields and orchards sold in Paju City between 1970 to 2000 was 8.2 ha and bought was 24.1 ha, showing a 3 fold difference between the land sold and bought. Although there was more land bought between 1970 to 1990, more land was sold between 1990 and 2000. The main purpose of buying land was to secure livelihood by expanding farming land, whereas the main purpose of selling land was to pay off debts and finance children's education.

In Muju County, the land bought and sold between 1970 and 2000 were 7.7 ha and 1.5 ha, respectively, in which the land bought was five fold more than that of land sold. The reasons for buying and selling were the same as in Paju city (Table 5). Thus, those wild grape farmers in Paju city and Muju County surveyed are seeking to expand their reproduction by securing livelihood by more land for farming (Kang et al., 2005).

Status of Household Income

In 2005, the average household income in Paju City and Muju County was 31 and 18 million won, respectively, in which Muju County's income was less than 60\% of Paju City. In 2004, the average income was 29 million won in each farm household but was 37 million won in each urban household (Ministry of Agriculture and Forestry, 2005). Among 23 households in Paju City, the total income was composed of $76 \%$ from agriculture and $15 \%$ from wild grapes. Those earning higher incomes were those in the 40's and 30's, those cultivating 1.0-1.5 ha of wild grape farms, and those cultivating more than 2.0 ha of agricultural land. Different from Paju City, the majority of income came from wild grape at $49 \%$ in Muju County, followed by agriculture at 34\%. Those earning higher incomes were those in their 30's, those cultivating 1.0-1.5 ha of wild grape farms, and those cultivating 1.0-1.5 ha of agricultural land (Table 6). On the other hand, in Paju City where more wild grapges are grown than in Muju County, wild grapes were less responsible for overall farm income because 18 households out of 23 households suffered from hailstone damage around the harvest time in 2005. The damage suffered was $6-70 \%$ of total income of the previous year. Three households did not harvest any wild grapes. However, only 6 households out of 22 households suffered slightly from hailstone damage in Muju County.

Future Plan on Agriculture and Forestry

On the other hand, the livelihood of those 23 house-

Table 3. Status of land cultivated

\begin{tabular}{|c|c|c|c|c|c|c|c|c|}
\hline Region & Total & $\begin{array}{c}\text { Avg. per } \\
\text { household }\end{array}$ & No land & $\begin{array}{c}\text { Less than } \\
0.5 \text { ha }\end{array}$ & $\begin{array}{l}0.5- \\
1.0 \text { ha }\end{array}$ & $\begin{array}{l}1.0- \\
1.5 \mathrm{ha}\end{array}$ & $\begin{array}{l}1.5- \\
2.0 \text { ha }\end{array}$ & $\begin{array}{c}\text { More than } \\
\text { 2.0ha }\end{array}$ \\
\hline Total & $\begin{array}{l}58.4 \\
(45)\end{array}$ & 1.3 & (2) & $\begin{array}{l}2.1 \\
(8)\end{array}$ & $\begin{array}{c}6.6 \\
(10)\end{array}$ & $\begin{array}{l}15.2 \\
(12)\end{array}$ & $\begin{array}{l}4.8 \\
(3)\end{array}$ & $\begin{array}{l}31.6 \\
(10)\end{array}$ \\
\hline Paju City & $\begin{array}{l}36.8 \\
(23)\end{array}$ & 1.6 & - & $\begin{array}{l}1.6 \\
(6)\end{array}$ & $\begin{array}{l}2.3 \\
(3)\end{array}$ & $\begin{array}{l}6.4 \\
(5)\end{array}$ & $\begin{array}{l}1.5 \\
(1)\end{array}$ & $\begin{array}{c}26.9 \\
(8)\end{array}$ \\
\hline Muju County & $\begin{array}{l}21.5 \\
(22)\end{array}$ & 1.0 & (2) & $\begin{array}{l}0.5 \\
(2)\end{array}$ & $\begin{array}{l}4.4 \\
(7)\end{array}$ & $\begin{array}{l}8.7 \\
(7)\end{array}$ & $\begin{array}{l}3.3 \\
(2)\end{array}$ & $\begin{array}{l}4.7 \\
(2)\end{array}$ \\
\hline
\end{tabular}

Note: The number in parenthesis is the number of households

Table 4. Status of crops cultivated

Unit: ha

\begin{tabular}{|c|c|c|c|c|c|c|c|c|c|c|c|}
\hline Region & Total & Rice & Gingseng & Zucchini & Vege. & Grain & $\begin{array}{c}\text { Red } \\
\text { pepper }\end{array}$ & Kadsura & Potato & Mushroom & Other \\
\hline $\begin{array}{l}\text { Total } \\
\text { ( } 45 \text { Household) }\end{array}$ & $\begin{array}{c}60.3 \\
(100.0)\end{array}$ & $\begin{array}{c}22.4 \\
(37.1)\end{array}$ & $\begin{array}{c}9.3 \\
(15.4)\end{array}$ & $\begin{array}{c}6.6 \\
(10.9)\end{array}$ & $\begin{array}{c}5.2 \\
(8.6)\end{array}$ & $\begin{array}{c}3.6 \\
(5.9)\end{array}$ & $\begin{array}{c}3.5 \\
(5.8)\end{array}$ & $\begin{array}{c}3.0 \\
(5.0)\end{array}$ & $\begin{array}{c}2.2 \\
(3.6)\end{array}$ & $\begin{array}{c}2.1 \\
(3.5)\end{array}$ & $\begin{array}{c}2.4 \\
(2.9)\end{array}$ \\
\hline $\begin{array}{l}\text { Paju City } \\
\text { ( } 23 \text { Household) }\end{array}$ & $\begin{array}{c}38.8 \\
(100.0)\end{array}$ & $\begin{array}{c}13.0 \\
(33.4)\end{array}$ & $\begin{array}{c}7.7 \\
(19.8)\end{array}$ & $\begin{array}{c}6.6 \\
(17.0)\end{array}$ & $\begin{array}{c}5.2 \\
(13.4)\end{array}$ & $\begin{array}{c}1.7 \\
(4.3)\end{array}$ & $\begin{array}{c}0.8 \\
(2.1)\end{array}$ & - & - & $\begin{array}{c}2.1 \\
(5.4)\end{array}$ & $\begin{array}{c}1.8 \\
(4.6)\end{array}$ \\
\hline $\begin{array}{l}\text { Muju County } \\
\text { ( } 22 \text { Household) }\end{array}$ & $\begin{array}{c}21.5 \\
(100.0)\end{array}$ & $\begin{array}{c}9.4 \\
(43.7)\end{array}$ & $\begin{array}{l}1.6 \\
(7.6)\end{array}$ & - & - & $\begin{array}{l}1.9 \\
(8.8)\end{array}$ & $\begin{array}{c}2.7 \\
(12.6)\end{array}$ & $\begin{array}{c}3.0 \\
(14.1)\end{array}$ & $\begin{array}{c}2.2 \\
(10.1)\end{array}$ & - & $\begin{array}{c}0.7 \\
(3.1)\end{array}$ \\
\hline
\end{tabular}

Note: The number in parenthesis is the ratio 
holds in Paju city was kept on by raising wild grapes in 7 households, grains and vegetables in 6 , and gingseng in 5. On the other hand in 22 households in Muju County, it was kept on by raising wild grapes in 14 households and grains and vegetables in 4 . When asked whether they would expand the land for farming and forestry, 17 households answered to maintain the current size, 4 to expand, and 2 no response. The main reasons for expansion were further cultivation of crops, such as ginseng and securing livelihood. The main reasons for

Table 5. Status of land purchase and sales

\begin{tabular}{|c|c|c|c|c|c|c|c|c|c|}
\hline \multirow{2}{*}{\multicolumn{2}{|c|}{ Classification }} & \multicolumn{5}{|c|}{ Bought } & \multicolumn{3}{|c|}{ Sold } \\
\hline & & Total & $\begin{array}{c}\text { Rice } \\
\text { paddies }\end{array}$ & Fields & Orchards & Forestry & Total & $\begin{array}{c}\text { Rice } \\
\text { paddies }\end{array}$ & Fields \\
\hline \multirow{6}{*}{$\begin{array}{l}\text { Paju } \\
\text { City }\end{array}$} & Total & 33.9 & 17.3 & 15.8 & 0.8 & 18.7 & 6.7 & 3.7 & 3.0 \\
\hline & Inheritance & 9.8 & 4.1 & 4.9 & 0.8 & 18.7 & - & - & - \\
\hline & 1970's & 13.0 & 6.0 & 7.0 & - & - & - & - & - \\
\hline & 1980's & 2.6 & 0.3 & 2.3 & - & - & 1.3 & 1.0 & 0.3 \\
\hline & 1990's & 7.9 & 6.6 & 1.3 & - & - & 2.9 & 2.0 & 0.9 \\
\hline & 2000's & 0.6 & 0.3 & 0.3 & - & - & 2.5 & 0.7 & 1.8 \\
\hline \multirow{6}{*}{$\begin{array}{l}\text { Muju } \\
\text { County }\end{array}$} & Total & 24.2 & 7.0 & 17.2 & - & 0.7 & 1.5 & 1.2 & 0.3 \\
\hline & Inheritance & 16.5 & 3.6 & 12.9 & - & 0.7 & - & - & - \\
\hline & 1970's & 1.0 & 0.5 & 0.5 & - & - & 0.1 & 0.1 & - \\
\hline & 1980's & 3.2 & 1.4 & 1.8 & - & - & - & - & - \\
\hline & 1990's & 2.6 & 0.6 & 2.0 & - & - & 0.2 & 0.2 & - \\
\hline & 2000's & 0.9 & 0.9 & - & - & - & 1.2 & 0.9 & 0.3 \\
\hline
\end{tabular}

Table 6. Status of household income

Unit: million won

\begin{tabular}{|c|c|c|c|c|c|c|c|c|c|c|c|}
\hline \multicolumn{3}{|c|}{ Classification } & \multirow{2}{*}{$\begin{array}{c}\text { Total } \\
717.6\end{array}$} & \multirow{2}{*}{$\begin{array}{c}\begin{array}{c}\text { Househ } \\
\text { old } \\
\text { avg. }\end{array} \\
31.2\end{array}$} & \multirow{2}{*}{$\begin{array}{c}\begin{array}{c}\text { Wild } \\
\text { grapes }\end{array} \\
106.1(14.8)\end{array}$} & \multirow{2}{*}{$\begin{array}{l}\text { Agriculture } \\
546.1(76.1)\end{array}$} & \multirow{2}{*}{$\begin{array}{c}\text { Fruits } \\
10.5\end{array}$} & \multirow{2}{*}{$\begin{array}{c}\begin{array}{c}\text { Regular } \\
\text { forestry } \\
\text { work }\end{array} \\
20.0\end{array}$} & \multirow{2}{*}{$\begin{array}{c}\begin{array}{c}\text { Temporary } \\
\text { forestry } \\
\text { work }\end{array} \\
5.9\end{array}$} & \multirow{2}{*}{$\begin{array}{c}\text { Lives- } \\
\text { tock } \\
\\
-\end{array}$} & \multirow{2}{*}{$\begin{array}{c}\text { Others } \\
29.0\end{array}$} \\
\hline \multirow{15}{*}{$\begin{array}{l}\text { Paju } \\
\text { City }\end{array}$} & & Total (23) & & & & & & & & & \\
\hline & & 30 's & 115.0 & 57.5 & $14.0(12.2)$ & $95.0(82.6)$ & - & - & - & - & 6.0 \\
\hline & \multirow{4}{*}{ Age } & 40 's & 228.0 & 114.0 & 38.0 (16.7) & $190.0(83.3)$ & - & - & - & - & - \\
\hline & & 50 's & 171.6 & 34.3 & $9.1(5.3)$ & $140.4(81.8)$ & _- & _- & 2.1 & - & 20.0 \\
\hline & & 60's & 158.0 & 22.6 & $23.2(14.7)$ & $109.5(69.3)$ & 1.5 & 20.0 & 3.8 & - & - \\
\hline & & Over 70 & 45.0 & 6.4 & $21.8(48.4)$ & $11.2(24.9)$ & 9.0 & - & - & - & 3.0 \\
\hline & \multirow{4}{*}{$\begin{array}{l}\text { Wild } \\
\text { grapes }\end{array}$} & Less than 0.5 ha & 177.1 & 22.1 & $9.1(5.1)$ & $148.4(83.8)$ & 2.0 & 10.0 & 5.6 & - & 2.0 \\
\hline & & $0.5-1.0$ ha & 166.2 & 18.5 & $27.7(16.7)$ & $98.7(59.4)$ & 8.5 & 10.0 & 0.3 & - & 21.0 \\
\hline & & $1.0-1.5 \mathrm{ha}$ & 42.0 & 42.0 & $10.0(23.8)$ & $32.0(76.2)$ & - & - & - & - & - \\
\hline & & More than $1.5 \mathrm{ha}$ & 332.3 & 41.5 & $59.3(17.8)$ & $267.0(80.3)$ & - & - & - & - & 6.0 \\
\hline & \multirow{5}{*}{$\begin{array}{l}\text { Agricul-t } \\
\text { ure land }\end{array}$} & Less than 0.5 ha & 51.4 & 8.6 & $15.6(30.4)$ & $8.0(15.6)$ & 2.0 & - & 3.8 & - & 22.0 \\
\hline & & $0.5-1.0 \mathrm{ha}$ & 23.2 & 7.7 & $11.0(47.4)$ & $4.2(18.1)$ & 7.0 & - & - & - & 1.0 \\
\hline & & $1.0-1.5 \mathrm{ha}$ & 131.3 & 26.3 & $26.8(20.4)$ & $102.4(78.0)$ & - & - & 2.1 & - & - \\
\hline & & $1.5-2.0 \mathrm{ha}$ & 7.2 & 7.2 & $0.7(9.7)$ & $5.0(69.4)$ & 1.5 & - & - & - & - \\
\hline & & More than 2.0 ha & 501.5 & 62.7 & $5.0(1.0)$ & $423.5(84.4)$ & - & 20.0 & 16.0 & - & 6.0 \\
\hline \multirow{14}{*}{$\begin{array}{l}\text { Muju } \\
\text { County }\end{array}$} & \multirow{6}{*}{ Age } & Total (22) & 399.1 & 18.1 & $193.9(48.6)$ & $134.9(33.8)$ & - & 18.0 & - & 3.0 & 33.4 \\
\hline & & 30 's & 42.0 & 42.0 & $12.0(28.6)$ & - & - & - & - & - & 30.0 \\
\hline & & 40 's & 82.9 & 20.7 & $24.0(29.0)$ & $40.9(49.3)$ & - & 18.0 & - & - & - \\
\hline & & 50 's & 50.5 & 16.8 & $16.5(32.7)$ & $33.0(65.3)$ & - & - & 1.0 & - & - \\
\hline & & 60 's & 125.7 & 25.1 & $83.0(66.0)$ & 23.5 (18.7) & - & - & 15.0 & 3.0 & 1.2 \\
\hline & & Over 70 & 98.1 & 10.9 & $58.4(59.5)$ & $37.6(38.3)$ & - & - & - & - & 2.2 \\
\hline & \multirow{3}{*}{$\begin{array}{l}\text { Wild } \\
\text { grapes }\end{array}$} & Less than 0.5 ha & 167.4 & 12.0 & $65.9(39.4)$ & $81.2(48.5)$ & - & 18.0 & - & - & 2.3 \\
\hline & & $0.5-1.0 \mathrm{ha}$ & 70.0 & 14.0 & $26.0(37.1)$ & $11.0(15.7)$ & - & - & 1.0 & 3.0 & 30.0 \\
\hline & & $1.0-1.5 \mathrm{ha}$ & 121.1 & 40.4 & $93.0(76.8)$ & $13.1(10.8)$ & - & - & 15.0 & - & - \\
\hline & \multirow{5}{*}{$\begin{array}{l}\text { Agricul-t } \\
\text { ure land }\end{array}$} & Less than 0.5 ha & 24.9 & 6.2 & $23.0(92.4)$ & 0.8 & - & - & - & - & 1.1 \\
\hline & & $0.5-1.0 \mathrm{ha}$ & 150.0 & 21.4 & $85.4(56.9)$ & $33.5(22.3)$ & - & - & - & - & 31.1 \\
\hline & & $1.0-1.5 \mathrm{ha}$ & 153.2 & 21.9 & $63.0(41.1)$ & $53.0(34.6)$ & _- & 18.0 & 15.0 & 3.0 & 1.2 \\
\hline & & $1.5-2.0 \mathrm{ha}$ & 29.0 & 14.5 & $7.5(25.9)$ & $21.5(74.1)$ & - & - & - & - & - \\
\hline & & More than $2.0 \mathrm{ha}$ & 42.0 & 21.0 & $15.0(35.7)$ & $26.0(61.9)$ & - & - & 1.0 & - & - \\
\hline
\end{tabular}

Note: 1) The number in parenthesis is the ratio

2) The number in parenthesis is the number of households 
maintaining the current level or reduction were lack of labor and no budget. In Muju County, 19 households answered to maintain the current level and 2, expand. As for forestry production, 4 and 2 households in Paju City and Muju County, respectively, wanted to expand. However, no household wanted to manage forestry. The main reasons for forestry expansion were herbal plant growth, fruit planting and resort construction. However, 5 of those who wanted to manage land and forestry expansion in both regions were in their 30's and 40's (Table 7).

\section{Status of Wild Grape Cultivation}

Status of Wild Grape Cultivation

The size of wild grape cultivation in Paju City was 0.9 ha per household, which was about twice as large as that in Muju County at 0.5 ha, because 5 households among 23 surveyed owned 2.8 ha in Paju City (Table 8). Status of Wild Grape Production

As for wild grape production in both regions in 2005 based on the grade, Paju city harvested a total of $106,050,000$ won with the premium grade being $37 \%$, medium grade $31 \%$, and low grade $20 \%$. Those farmers in their 40's and 50's produced about $60 \%$ of premium grade wild grapes but those in their 60's and 70's, only about 20\% level. However, there were not significant difference in wild grape cultivation size and agriculture land. Unlike Paju City, other individual sales were responsible for 54\% of sales in Muju County and were responsible for more than $50 \%$ according to each factor and grade (Table 9). Generally, the production of wild grapes started from middle of September in both regions, and they were sold by grades like 5 million won with premium, 4 million with medium, and 3 million won with low grade.

\section{Status of Production Cost}

Herbal treatment and compost were responsible for the majority of material cost for wild grapes at $81 \%$ and 90\% in Paju City and Muju County, respectively. The average material cost for each household was 2.41 million won in Paju City and 970,000 won in Muju County. It was larger in both regions as the size of wild grape cultivation increased (Table 10). On the other hand, 14 households in Paju City built a partial or complete facility preventing rain affecting early falling and brix level, whereas no household used this facility in Muju County.

The majority of labor cost went in for harvesting in Paju city and Muju County was 38\% and 36\%, respectively, followed by pruning and land lease. The average labor cost per each household was 1.92 million won in Paju City and 480 thousand won in Muju County, showing more labor cost as the size of cultivation increased. In Muju County, the material cost and labor cost out of

Table 7. Future plan on agriculture and forestry

\begin{tabular}{|c|c|c|c|c|c|c|c|c|c|c|c|c|c|c|}
\hline & \multirow{2}{*}{\multicolumn{2}{|c|}{ Classification }} & \multicolumn{5}{|c|}{ Size of agriculture land } & \multicolumn{4}{|c|}{ Size of forestry } & \multicolumn{3}{|c|}{ Heirs } \\
\hline & & & Total & $\begin{array}{l}\text { Expan- } \\
\text { sion }\end{array}$ & $\begin{array}{c}\text { Current } \\
\text { level }\end{array}$ & $\begin{array}{l}\text { Reduc- } \\
\text { tion }\end{array}$ & $\begin{array}{c}\text { No } \\
\text { answer }\end{array}$ & Total & $\begin{array}{c}\text { Expan } \\
\text {-sion }\end{array}$ & $\begin{array}{c}\text { Current } \\
\text { level }\end{array}$ & $\begin{array}{c}\text { No } \\
\text { answer }\end{array}$ & Total & Heir & $\begin{array}{l}\text { No } \\
\text { heir }\end{array}$ \\
\hline \multirow{6}{*}{$\begin{array}{l}\text { Paju } \\
\text { City }\end{array}$} & \multirow{6}{*}{ Age } & Total (23) & 23 & 4 & 17 & - & 2 & 23 & 4 & - & 19 & 23 & 3 & 30 \\
\hline & & 30's & 2 & 1 & 1 & - & - & 2 & 2 & - & - & 2 & - & 2 \\
\hline & & 40's & 2 & - & 2 & - & - & 2 & - & - & 2 & 2 & - & 2 \\
\hline & & 50 's & 5 & 2 & 2 & - & 1 & 5 & 2 & - & 3 & 5 & 1 & 4 \\
\hline & & 60's & 7 & 1 & 6 & - & - & 7 & - & - & 7 & 7 & 1 & 6 \\
\hline & & Over 70 & 7 & - & 6 & - & 1 & 7 & - & - & 7 & 7 & 1 & 6 \\
\hline \multirow{6}{*}{$\begin{array}{c}\text { Muju } \\
\text { County }\end{array}$} & \multirow{6}{*}{ Age } & Total (22) & 22 & 2 & 19 & 1 & - & 22 & 2 & 19 & 1 & 22 & - & 22 \\
\hline & & 30's & 1 & - & 1 & - & - & 1 & 1 & - & - & 1 & - & 1 \\
\hline & & 40's & 4 & 2 & 2 & - & - & 4 & 1 & 2 & 1 & 4 & - & 4 \\
\hline & & 50 's & 3 & - & 3 & - & - & 3 & - & 3 & - & 3 & - & 3 \\
\hline & & 60's & 5 & - & 5 & - & - & 5 & - & 5 & - & 5 & - & 5 \\
\hline & & Over 70 & 9 & - & 8 & 1 & - & 9 & - & 9 & - & 9 & - & 9 \\
\hline
\end{tabular}

Note: The number in parenthesis is the number of households

Table 8. Wild grape cultivation size

\begin{tabular}{|c|c|c|c|c|c|c|}
\hline Classification & Total & $\begin{array}{c}\text { Average } \\
\text { household }\end{array}$ & Less than 0.5 ha & 0.5-1.0ha & 1.0-1.5ha & More than 1.5ha \\
\hline Total & $\begin{array}{l}32.4 \\
(45)\end{array}$ & 0.7 & $\begin{array}{c}6.6 \\
(22)\end{array}$ & $\begin{array}{c}8.5 \\
(14)\end{array}$ & $\begin{array}{l}4.8 \\
(4)\end{array}$ & $\begin{array}{l}13.8 \\
(5)\end{array}$ \\
\hline Paju City & $\begin{array}{l}21.6 \\
(23)\end{array}$ & 0.9 & $\begin{array}{l}2.5 \\
(8)\end{array}$ & $\begin{array}{l}5.3 \\
(9)\end{array}$ & $\begin{array}{l}1.0 \\
(1)\end{array}$ & $\begin{array}{l}13.8 \\
(5)\end{array}$ \\
\hline Muju County & $\begin{array}{l}10.8 \\
(22)\end{array}$ & 0.5 & $\begin{array}{c}4.1 \\
(14)\end{array}$ & $\begin{array}{l}3.2 \\
(5)\end{array}$ & $\begin{array}{l}3.5 \\
(3)\end{array}$ & - \\
\hline
\end{tabular}

Note: The number in parenthesis is the number of households 
the total production cost was $16 \%$, whereas they were responsible for $94 \%$ in Paju City because most cost went early stage but the production level decreased significantly due to hailstone right before harvest (Table 11). On the other hand, those farmers in Paju City were compensated with goods, such as fertilizers and pesticides for hailstone damage, whereas there were farms that abandon recovery due to lack of compensation and budget for facility preventing rain damage. Although there was mild hailstone in Muju County, no compensation was made (Table 11).

Status of Wild Grape Sales Distribution and Production Facilities

In Paju City, 90\% of wild grapes produced was supplied to the processing center within the region, and those in their 30's sold their harvest through camps attracting people to enjoy forest. In Muju County, 40\% was sold to processing centers but more than 50\% was sold directly with each farmer processing wild grapes into juice and wine or fruits. Most sold directly to those people they knew through their children and relatives and were pessimistic about direct sales. Farmers in both regions did not have a cooperative center to secure distribution channel or through the Internet for better profits. Especially, the processing centers in Muju County were buying less at lower cost so that the farmers were concerned with securing proper distribution channels (Table 12).

On the other hand, machinery owned by households for the production of wild grapes and agricultural products in 45 households showed that they owned 30 management equipment, 17 dryers and 11 cultivators. Dryers were used more for agricultural products other than wild grapes, and only 2 households owned cooling system in Paju City that could increase the possibility of distribution channels by controlling the amount released (Table 13).

Wild Grape Production Plan

Among 23 households in Paju City, only 2 were planning to expand their wild grape cultivation, 18 to maintain at the current level, and 3 to reduce. Among those 3 households that were planning to reduce their culti-

Table 9. Production amount according to grades

Unit: 10,000 won

\begin{tabular}{|c|c|c|c|c|c|c|c|c|c|}
\hline \multicolumn{3}{|c|}{ Classification } & \multirow{2}{*}{$\begin{array}{c}\text { Total } \\
\begin{array}{c}10,605 \\
(100.0)\end{array}\end{array}$} & \multirow{2}{*}{$\begin{array}{c}\begin{array}{c}\text { Household } \\
\text { avg. }\end{array} \\
461.1\end{array}$} & \multirow{2}{*}{$\begin{array}{c}\text { Premium } \\
\begin{array}{c}3,883 \\
(36.6)\end{array}\end{array}$} & \multirow{2}{*}{$\begin{array}{c}\text { Medium } \\
\begin{array}{c}3,237 \\
(30.5)\end{array}\end{array}$} & \multirow{2}{*}{$\begin{array}{l}\text { Low } \\
2,115 \\
(19.9)\end{array}$} & \multirow{2}{*}{$\begin{array}{c}\text { No gradel } \\
300 \\
(2.8)\end{array}$} & \multirow{2}{*}{$\begin{array}{c}\text { Others } \\
\begin{array}{c}1,070 \\
(10.1)\end{array}\end{array}$} \\
\hline \multirow{6}{*}{$\begin{array}{l}\text { Paju } \\
\text { City }\end{array}$} & \multirow{6}{*}{ Age } & Total (23) & & & & & & & \\
\hline & & 30's & 1,400 & 700.0 & 120 & 200 & 80 & - & 1,000 \\
\hline & & 40's & 3,800 & $1,900.0$ & 2,190 & 880 & 730 & - & - \\
\hline & & 50 's & 905 & 181.0 & 500 & 365 & 40 & - & - \\
\hline & & 60's & 2,320 & 331.4 & 603 & 1,102 & 615 & - & - \\
\hline & & Over 70 & 2,180 & 311.4 & 470 & 690 & 650 & 300 & 70 \\
\hline \multirow{6}{*}{$\begin{array}{c}\text { Muju } \\
\text { County }\end{array}$} & \multirow{6}{*}{ Age } & Total (22) & $\begin{array}{c}19,390 \\
(100.0)\end{array}$ & 881.4 & $\begin{array}{l}3,814 \\
(19.7)\end{array}$ & $\begin{array}{l}363.2 \\
(1.9)\end{array}$ & $\begin{array}{c}4,526 \\
(23.3)\end{array}$ & $\begin{array}{c}180 \\
(0.9)\end{array}$ & $\begin{array}{c}10,506.8 \\
(54.2)\end{array}$ \\
\hline & & 30's & 1,200 & $1,200.0$ & 150 & - & - & - & 1,050 \\
\hline & & 40's & 2,400 & 600.0 & 372 & 205.2 & 740 & - & $1,082.8$ \\
\hline & & 50 's & 1,650 & 550.0 & 432 & 68 & 150 & - & 1,000 \\
\hline & & 60's & 8,300 & $1,660.0$ & 1,330 & - & 3,466 & - & 3,504 \\
\hline & & Over 70 & 5,840 & 648.9 & 1,530 & 90 & 170 & 180 & 3870 \\
\hline
\end{tabular}

Note: The number in parenthesis is the number of households

Table 10. Status of production cost (Material cost)

Unit: 10,000 won

\begin{tabular}{|c|c|c|c|c|c|c|c|c|c|}
\hline \multicolumn{3}{|c|}{ Classification } & Total & \multirow{2}{*}{$\begin{array}{c}\begin{array}{c}\text { House- } \\
\text { hold } \\
\text { avg. }\end{array} \\
241.4\end{array}$} & \multirow{2}{*}{$\begin{array}{c}\text { Herval } \\
\text { treatment, } \\
\text { fertilizer }\end{array}$} & \multirow{2}{*}{$\begin{array}{c}\text { Plastic } \\
746 \\
(13.4)\end{array}$} & \multirow{2}{*}{$\begin{array}{c}\text { Electricity } \\
270 \\
(4.9)\end{array}$} & \multirow{2}{*}{$\begin{array}{r}\text { Oil } \\
\\
\end{array}$} & \multirow{2}{*}{$\begin{array}{r}\text { Box } \\
50\end{array}$} \\
\hline & & Total & $\begin{array}{c}5,553 \\
(100.0)\end{array}$ & & & & & & \\
\hline Paju & Wild & Less than 0.5 ha & 281 & 35.1 & 69 & 212 & - & - & - \\
\hline City & grapes & $0.5-1.0$ ha & 533 & 59.2 & 439 & 34 & 10 & - & 50 \\
\hline & & $1.0-1.5 \mathrm{ha}$ & 425 & 425 & 195 & 200 & 30 & - & - \\
\hline & & More than 1.5 ha & 4,314 & 862.8 & 3,780 & 300 & 230 & 4 & - \\
\hline \multirow{4}{*}{$\begin{array}{c}\text { Muju } \\
\text { County }\end{array}$} & \multirow{4}{*}{$\begin{array}{l}\text { Wild } \\
\text { grapes }\end{array}$} & Total & $\begin{array}{c}2,128 \\
(100.0)\end{array}$ & 96.7 & $\begin{array}{l}1,920 \\
(90.2)\end{array}$ & 60 & 8 & 70 & 70 \\
\hline & & Less than 0.5 ha & 638 & 45.6 & 579 & - & 4 & 20 & 35 \\
\hline & & $0.5-1.0 \mathrm{ha}$ & 540 & 108.0 & 445 & 60 & - & - & 35 \\
\hline & & $1.0-1.5 \mathrm{ha}$ & 950 & 316.7 & 896 & - & 4 & 50 & - \\
\hline
\end{tabular}

Note: The number in parenthesis is the ratio (\%) 
vation size, each one was in the 30's, 40's and 50's. The size of cultivation was $1.0-1.5$ ha in 1 household and more than 1.5 ha in 2 households. The size of agricultural land was more than 2.0 ha in 2 households. Thus, these households had relatively large wild grape cultivation and agricultural land. In Muju County, 15 households reported to maintain the current size, 7 to reduce and none to expand. Among those 7 household planning to reduce, 4 were in their 60's and over 70 years age, 5 had less than 0.5 ha of cultivation size, but the size of agricultural land varied. However, most of the households who answered to maintain their cultivation size, because their could not find more appropriate product despite lack of labor, difficulty in finding distribution channels, and reduction in wild grape cost and harvest (Table 14).

Table 11. Wild grape production cost (labor cost)

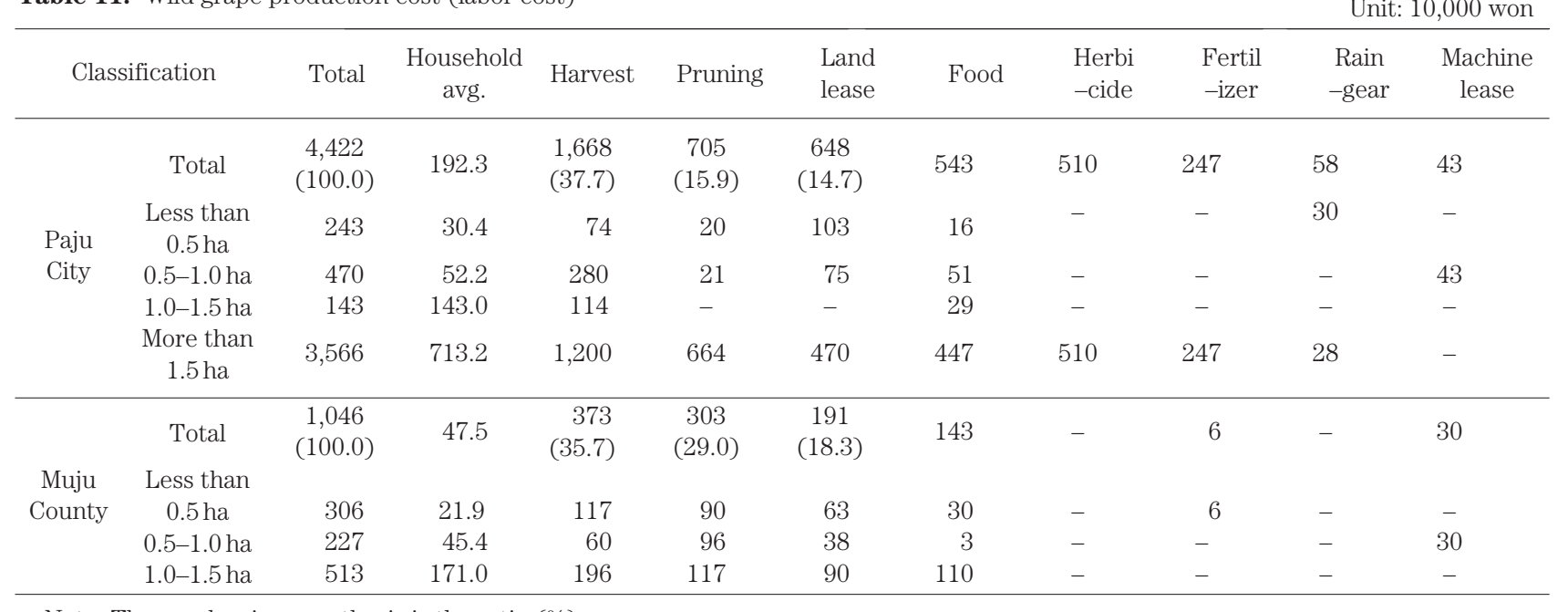

Note: The number in parenthesis is the ratio (\%)

Table 12. Status of sales and distribution

Unit: 10,000 won

\begin{tabular}{|c|c|c|c|c|c|c|c|c|}
\hline & \multirow{2}{*}{\multicolumn{2}{|c|}{ Classification }} & \multirow[b]{2}{*}{ Total } & \multicolumn{4}{|c|}{ Fruit sales } & \multirow{2}{*}{$\begin{array}{c}\begin{array}{c}\text { Processed } \\
\text { goods sales }\end{array} \\
\text { Juice and } \\
\text { wine sales }\end{array}$} \\
\hline & & & & $\begin{array}{c}\text { Processing } \\
\text { centers }\end{array}$ & $\begin{array}{l}\text { Sold to } \\
\text { health } \\
\text { centers }\end{array}$ & $\begin{array}{c}\text { Direct sales } \\
\text { at camps }\end{array}$ & $\begin{array}{c}\text { Sales to } \\
\text { Fruit } \\
\text { distributors }\end{array}$ & \\
\hline \multirow{11}{*}{$\begin{array}{l}\text { Paju } \\
\text { City }\end{array}$} & \multirow{7}{*}{ Age } & \multirow{2}{*}{ Total (23) } & 10,605 & 9,535 & 70 & \multirow{2}{*}{\multicolumn{2}{|c|}{$\begin{array}{l}1,000 \\
(94)\end{array}$}} & \multirow[b]{2}{*}{-} \\
\hline & & & $(100.0)$ & $(89.9)$ & $(0.7)$ & $(9.4)$ & & \\
\hline & & 30 's & 1,400 & 400 & - & \multicolumn{2}{|l|}{1,000} & - \\
\hline & & \multirow{2}{*}{$\begin{array}{l}40 \text { 's } \\
50 \text { 's }\end{array}$} & 3,800 & 3,800 & - & \multicolumn{2}{|r|}{-} & - \\
\hline & & & 905 & 905 & - & \multicolumn{2}{|r|}{-} & - \\
\hline & & 60's & 2,320 & 2,320 & - & \multicolumn{2}{|r|}{-} & - \\
\hline & & Over 70 & 2,180 & 2,110 & 70 & - & - & - \\
\hline & \multirow{4}{*}{$\begin{array}{l}\text { Wild } \\
\text { grape }\end{array}$} & \multicolumn{2}{|c|}{ Less than 0.5 ha 910} & 910 & - & - & \multirow{2}{*}{-} & - \\
\hline & & $0.5-1.0$ ha & 2,770 & 2,700 & 70 & - & & - \\
\hline & & \multirow{2}{*}{$\begin{array}{c}1.0-1.5 \text { ha } \\
\text { More than } 1.5 \text { ha }\end{array}$} & 1,000 & 1,000 & - & - & - & - \\
\hline & & & 5,925 & 4,925 & - & 1,000 & - & - \\
\hline \multirow{10}{*}{$\begin{array}{l}\text { Muju } \\
\text { County }\end{array}$} & \multirow{7}{*}{ Age } & \multirow[b]{2}{*}{ Total (22) } & 19,390 & 9,457 & 2,170 & \multirow[b]{2}{*}{-} & 2,300 & \multirow{2}{*}{$\begin{array}{l}5,463 \\
(28.2)\end{array}$} \\
\hline & & & $(100.0)$ & $(48.8)$ & $(11.2)$ & & $(11.9)$ & \\
\hline & & 30's & 1,200 & 150 & - & - & - & 1,050 \\
\hline & & 40 's & 2,400 & 1,317 & - & - & - & 1,083 \\
\hline & & 50's & 1,650 & 650 & - & - & - & 1,000 \\
\hline & & 60 's & 8,300 & 5,030 & 2,170 & - & - & 1,100 \\
\hline & & Over 70 & 5,840 & 2,310 & - & - & 2,300 & 1,230 \\
\hline & & Less than 0.5 ha & 6,590 & 4,161 & - & - & - & 2,429 \\
\hline & wild & $0.5-1.0 \mathrm{ha}$ & 3,500 & 1,216 & - & - & - & 2,284 \\
\hline & & $1.0-1.5$ ha & 9,300 & 4,080 & 2,170 & - & 2,300 & 750 \\
\hline
\end{tabular}

Note: 1 . The number in parenthesis is the ratio (\%)

2 . The number in parenthesis is the number of households 
Table 13. Status of equipment used for wild grape production

\begin{tabular}{|c|c|c|c|c|c|c|c|c|c|c|c|}
\hline \multicolumn{2}{|c|}{ Classification } & Total & $\begin{array}{c}\text { Spra- } \\
\text { yers }\end{array}$ & $\begin{array}{l}\text { Trac- } \\
\text { tors }\end{array}$ & $\begin{array}{c}\text { Management } \\
\text { equipment }\end{array}$ & $\begin{array}{l}\text { Brush } \\
\text { Cutter }\end{array}$ & Dryers & $\begin{array}{l}\text { Cooling } \\
\text { facility }\end{array}$ & $\begin{array}{l}\text { Farm } \\
\text { tools }\end{array}$ & $\begin{array}{l}\text { Culti- } \\
\text { vators }\end{array}$ & $\begin{array}{l}\text { Com- } \\
\text { bines }\end{array}$ \\
\hline \multirow{5}{*}{$\begin{array}{l}\text { Paju } \\
\text { City }\end{array}$} & Total & 47 & 1 & 7 & 14 & 1 & 10 & 2 & 2 & 9 & 1 \\
\hline & Less than 0.5 ha & 3 & - & - & 1 & - & 2 & - & - & - & - \\
\hline & $0.5-1.0 \mathrm{ha}$ & 12 & - & - & 6 & - & 3 & - & - & 3 & - \\
\hline & $1.0-1.5 \mathrm{ha}$ & 6 & - & 1 & 1 & - & 1 & - & - & 3 & - \\
\hline & More than 1.5 ha & 26 & 1 & 6 & 6 & 1 & 4 & 2 & 2 & 3 & 1 \\
\hline \multirow{4}{*}{$\begin{array}{l}\text { Muju } \\
\text { County }\end{array}$} & Total & 31 & - & - & 16 & - & 7 & - & - & 2 & 1 \\
\hline & Less than 0.5 ha & 24 & - & - & 11 & - & 6 & - & - & 2 & 1 \\
\hline & $0.5-1.0 \mathrm{ha}$ & 3 & - & - & 3 & - & - & - & - & - & - \\
\hline & $1.0-1.5$ ha & 4 & - & - & 2 & - & 1 & - & - & - & - \\
\hline
\end{tabular}

Note: The number in parenthesis is the ratio (\%)

Table 14. Exports and imports of oak mushrooms

\begin{tabular}{|c|c|c|c|c|c|c|}
\hline \multirow{2}{*}{\multicolumn{3}{|c|}{ 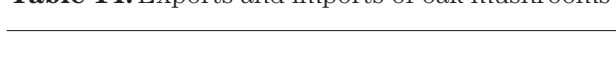 }} & & & & Unit : \\
\hline & & & \multicolumn{4}{|c|}{ Size } \\
\hline \multicolumn{2}{|c|}{ Classification } & & Total & Expand & Current level & Reduc \\
\hline \multirow{9}{*}{ Paju City } & \multirow{7}{*}{ Age } & Total (23) & 23 & 2 & 18 & 3 \\
\hline & & 30 's & 2 & - & 1 & 1 \\
\hline & & 40 's & 2 & - & 1 & 1 \\
\hline & & 50 's & 5 & 2 & 2 & 1 \\
\hline & & 60 's & 7 & - & 7 & - \\
\hline & & Over 70 & 7 & - & 7 & - \\
\hline & & Less than 0.5 ha & 8 & 1 & 7 & - \\
\hline & & 0.5-1.0 ha & 9 & 1 & 8 & - \\
\hline & Wild grape & $1.0-1.5 \mathrm{ha}$ & 1 & - & - & 1 \\
\hline \multirow{10}{*}{ Muju County } & & More than $1.5 \mathrm{ha}$ & 5 & - & 3 & 2 \\
\hline & \multirow{7}{*}{ Age } & Total (22) & 22 & - & 15 & 7 \\
\hline & & 30 's & 1 & - & & 1 \\
\hline & & 40 's & 4 & - & 3 & 1 \\
\hline & & 50 's & 3 & - & 2 & 1 \\
\hline & & 60 's & 5 & - & 4 & 1 \\
\hline & & Over 70 & 9 & - & 6 & 3 \\
\hline & & Less than 0.5 ha & 14 & - & 9 & 5 \\
\hline & \multirow{2}{*}{ Wild grape } & $0.5-1.0$ ha & 5 & - & 4 & 1 \\
\hline & & $1.0-1.5 \mathrm{ha}$ & 3 & - & 2 & 1 \\
\hline
\end{tabular}

Note: The number in parenthesis is the number of households

\section{CONCLUSION}

1. Those labor in Paju City and Muju County were older than 60 's at $61 \%$ and $64 \%$, respectively; the average agricultural land size per household was 1.6 ha and 1.0 ha, respectively; and more land was purchased than selling in which the land purchased was 3-5 times more than land sold in both regions.

2. The average income per household was 31 million won and 18 million won in Paju City and Muju County, respectively, so that it was less than $60 \%$ in Muju County compared with Paju City. In 2004, the average income in rural family and urban family was 29 million won and 37 million won, respectively. The rate income coming from wild grape was 15\% in Paju City and 49\% in Muju County.

3. For future planning, 7 households out of 23 in Paju City and 14 out of 22 in Muju County selected wild grapes as the main crop for their future. However, 6 out of 45 wanted to expand the size of cultivation of forestry for the cultivation of herbal plants and fruits. But none of the households wanted to manage forestry.

4. The average size of wild grape cultivation in Paju City and Muju County was 0.9 ha and 0.5 h, respectively. In 2005, the average cost of production per household was 4.61 million won and 8.81 million won, respectively. The ratio of materials and labor cost in Paju City and Muju County was 94\% and 16\%, respectively.

5. In Paju City, 90\% of total wild grapes produced was sold to processing plants in the region. But $51 \%$ in Muju County was sold by the individual grower. Only 2 households in Paju City and none in Muju County had a cooling storage system, and 14 households in Paju City had a partial or complete rain guard system but none in Muju County. 
6. 3 households and 7 in Paju City and Muju County, respectively, were planning to reduce the cultivation size but most planned to maintain the current level.

The following are the challenges found by reviewing the results of this study.

1. Rain guard and pest controlling systems and eco-friendly method of cultivation are needed to produce premium wild grapes, requiring systematic techniques to cultivate wild grapes.

2. In order to secure stable income level, wild grape growers need not be dependent upon those local buyers, and should find other methods of distribution such as selling wild grapes through camps hosted by jointly by growers by forming a cooperative and develop new methods of distribution such as through the Internet. Moreover, more publicity is needed to promote wild grape wine, which is recognized by the public less than traditional Korean or fruit wines.

3. There is a problem in storing fresh wild grapes but wild grape juice or wine could be stored for long time so they could be sold throughout the year and open up further markets. However, wine in Muju County was produced by each household so its taste is different with no standard methods of making wild grape wine so that measures are needed to overcome this problem.

4. The quality of fresh fruits stored at room temperature goes down with insect development, and they could not be sold individually. Thus, support and research are needed to build a long storage system to store and expand distribution channels of wild grapes that are produced throughout Korea almost at the same time.

5. Currently, processing plants play a significant role in providing the basis for wild grape production by purchasing wild grapes. However, inventory increases and lack of sales will affect growers significantly.
Thus, financial and facility support is needed for long-term storage system that could add value to wild grapes such as storing them in wine.

6. In Paju City, hailstone damage was paid with goods such as fertilizers and pesticides and no support was given to damaged facility so that some growers abandoned growing wild grapes altogether. Thus, local governments should provide a certain level of cost for recoverying from natural disasters.

7. Lastly, wild grapes drawing attention as a short-term income generating crop as a forestry product, giving a competitive edge to Korean farmers for the Uruguay Round, can not be sold readily and prepossessing plants have a difficulty distributing their goods. Thus, those farms cultivating wild grapes are considering to reduce cultivating size, concerned over distribution channels and lag willingness. Nonetheless, the demand is not expected to rise sharply in recent future due to price drop, competition with imported wine, and public not being aware of wild grapes. Furthermore, wild grape growers are faced with financial burden and labor shortage with no definite distribution channel on top of a difficulty finding a substitute crop.

\section{REFERENCES}

Kang, H. M., S. I. Choi., J. S. Kim., I. S. Jeong., S. W, Oh., S. H. Lee and N. Sato. 2005 A Study on the Development Project of Mountain Settlements in Korea. J. Fac. Agr. Kyushu Univ., 50 (1): 295-311

Kim, J. S. and W. J. Kim. 1995 Economic Analysis of Income Forest Products. FRI. J. For. Sci., 5 (2): 87-93

Korea Forest Service. 1993 Characteristics of short-term income forest products and method of cultivation. 172-174

Ministry of Agriculture and Forestry. 2005 Statistics of Agriculture and Forestry. 114-129

Muju County in North Jeolla Province. 2006 Internal Information

Paju City in Gyeonggi Province. 2006 Internal Information 